This item was submitted to Loughborough's Research Repository by the author.

Items in Figshare are protected by copyright, with all rights reserved, unless otherwise indicated.

\title{
Artificial linear brush abrasion of coatings for photovoltaic module first- surfaces
}

PLEASE CITE THE PUBLISHED VERSION

https://doi.org/10.1016/j.solmat.2020.110757

PUBLISHER

Elsevier

VERSION

AM (Accepted Manuscript)

PUBLISHER STATEMENT

This paper was accepted for publication in the journal Solar Energy Materials and Solar Cells and the definitive published version is available at https://doi.org/10.1016/j.solmat.2020.110757

LICENCE

CC BY-NC-ND 4.0

\section{REPOSITORY RECORD}

Newkirk, JM, I Nayshevsky, A Sinha, AM Law, QF Xu, B To, PF Ndione, et al.. 2020. "Artificial Linear Brush Abrasion of Coatings for Photovoltaic Module First-surfaces". Loughborough University.

https://hdl.handle.net/2134/13012613.v1. 


\section{Short Abstract:}

Artificial linear brush abrasion was examined to explore the durability of representative PV firstsurfaces. Specimens examined include silane surface functionalized-, roughened (etched)-, porous silica coated-, fluoropolymer coated-, and ceramic ( $\mathrm{TiO} 2$ or $\mathrm{ZrO} 2 / \mathrm{SiO} 2 / \mathrm{ZrO} 2 / \mathrm{SiO} 2$ ) coated-glass, which are compared to monolithic-poly(methyl methacrylate) and -glass coupons. Characterization methods included: optical microscopy, UV-VIS-NIR spectroscopy, sessile drop goniometry, white light interferometry, atomic force microscopy (AFM), and depth profiling X-ray photoelectron spectroscopy (XPS). The corresponding characteristics examined include: surface morphology, transmittance (i.e., optical performance), surface energy (water contact angle), surface roughness, scratch-width and -depth, and chemical composition, respectively. The study here was performed to determine coating failure modes; identify characterization methods that can detect nascent failures; compare the durability of popular contemporary coating materials; and identify their corresponding damage characteristics; and compare between slurry and dry dust abrasion. 


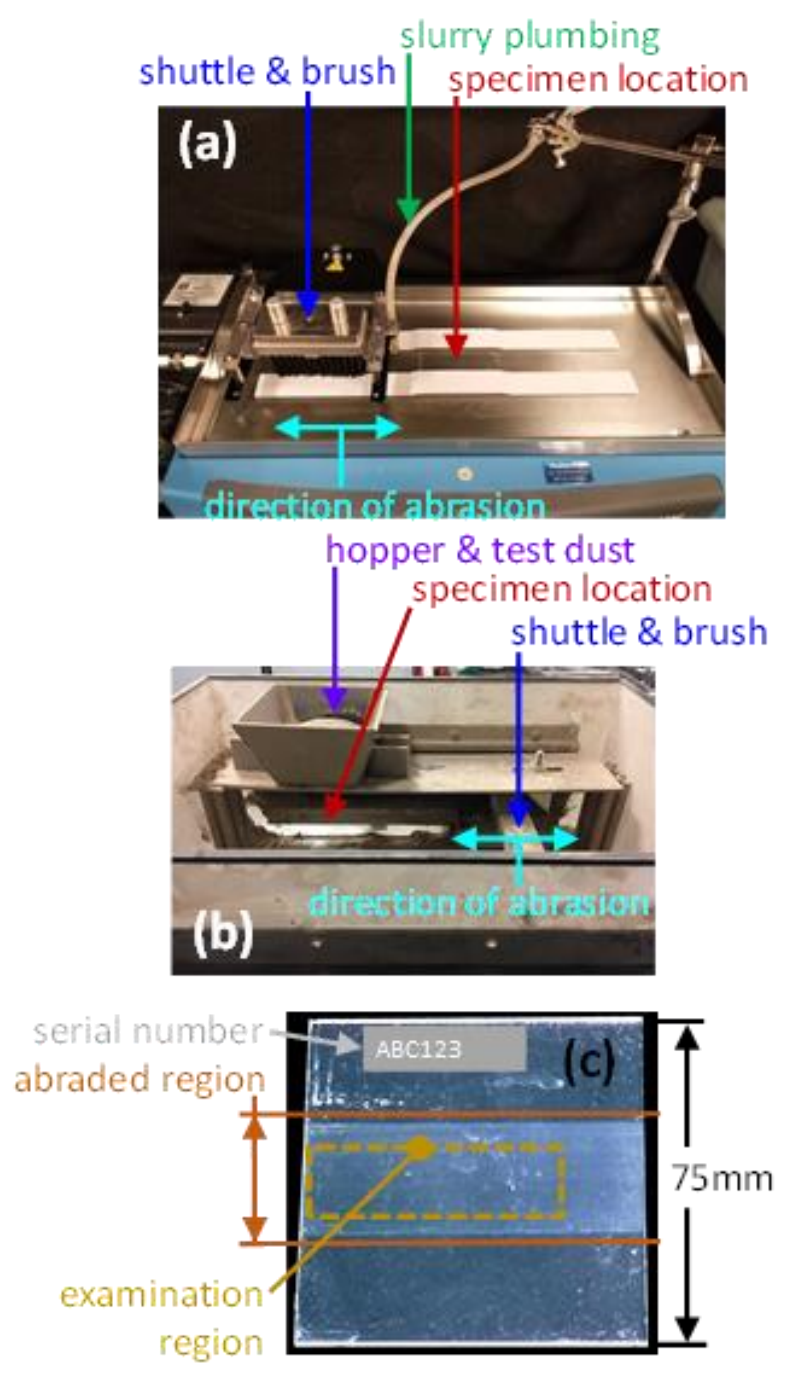

- Correlation between transmittance, yellowness index, surface energy, and surface roughness consistent with history of film degradation.

- Abrasion damage primarily resulted from the facets and edges of dust particles and/or brush bristles, i.e., localized abrasion sources.

- A variety of longevities from 100 cycles to 1000 cycles to 10000 cycles was observed for the representative specimens here.

- Details of the test parameters as well as post examination suggest improvement of the linear artificial brush abrasion method. 


\title{
Artificial linear brush abrasion of coatings for photovoltaic module first-surfaces
}

\author{
Jimmy M. Newkirk, ${ }^{1}$ Illya Nayshevsky, ${ }^{2,3}$ Archana Sinha,${ }^{4}$ Adam M. Law,${ }^{5}$ QianFeng Xu, ${ }^{6}$ Bobby To, ${ }^{1}$ Paul F. \\ Ndione, ${ }^{1}$ Laura T. Schelhas, ${ }^{4}$ John M. Walls, ${ }^{5}$ Alan M. Lyons, ${ }^{2,3,6}$ and David C. Miller ${ }^{1 *}$ \\ ${ }^{1}$ National Center for Photovoltaics, National Renewable Energy Laboratory, Golden, CO 80401-3214 \\ ${ }^{2}$ College of Staten Island, City University of New York, 2800 Victory Blvd., Staten Island, NY 10314 \\ ${ }^{3}$ The Graduate Center, City University of New York, $3655^{\text {th }}$ Avenue, New York, NY 10016 \\ ${ }^{4}$ SLAC National Accelerator Laboratory, Menlo Park, CA, 94025, USA \\ ${ }^{5}$ CREST, Wolfson School of Mechanical, Electrical and Manufacturing Engineering, Loughborough University, Loughborough LE11 \\ 3TU, United Kingdom \\ ${ }^{6}$ ARL Designs LLC, 215 W. $125^{\text {th }}$ Street $4^{\text {th }}$ Fl., New York, NY 10027 \\ *Corresponding author: David.Miller@nrel.gov, +1 3033847855, https://www.nrel.gov/pv/accelerated-testing- \\ analysis.html
}

\section{ABSTRACT}

Natural soiling and the subsequent requisite cleaning of photovoltaic (PV) modules result in abrasion damage to the cover glass. The durability of the front glass has important economic consequences, including determining the use of anti-reflective and/or anti-soiling coatings as well as the method and frequency of operational maintenance (cleaning). Artificial linear brush abrasion using Nylon 6/12 bristles was therefore examined to explore the durability of representative PV first-surfaces, i.e., the surface of a module incident to direct solar radiation. Specimens examined include silane surface functionalized-, roughened (etched)-, porous silica-coated-, fluoropolymer-coated-, and ceramic $\left(\mathrm{TiO}_{2}\right.$ or $\left.\mathrm{ZrO}_{2} / \mathrm{SiO}_{2} / \mathrm{ZrO}_{2} / \mathrm{SiO}_{2}\right)$-coated-glass, which are compared to monolithic-poly(methyl methacrylate) and -glass coupons. Characterization methods used in this study include: optical microscopy, ultraviolet-visible-near-infrared (UV-VIS-NIR) spectroscopy, sessile drop goniometry, white-light interferometry, atomic force microscopy (AFM), and depth-profiling X-ray photoelectron spectroscopy (XPS). The corresponding characteristics examined include: surface morphology, transmittance (i.e., optical performance), surface energy (water contact angle), surface roughness, scratch width and depth, and chemical composition, respectively. The study here was performed to determine coating failure modes; identify characterization methods that can detect nascent failures; compare the durability of popular contemporary coating materials; identify their corresponding damage characteristics; and compare slurry and dry-dust abrasion. This study will also aid in developing an abrasion standard for the PV industry.

\section{KEYWORDS}

abrasion, anti-reflective coating, anti-soiling coating, erosion, operations maintenance, PMMA 


\section{INTRODUCTION}

Insolation, temperature, and external contamination are the three primary natural factors affecting electricity generation in solar photovoltaic (PV) devices. Regarding the latter, natural soiling (contamination, including inorganic and organic matter) on the surface of PV modules can gradually reduce performance in the order of $1 \% \cdot$ day $^{-1}$ in the insolation-rich Middle East and North Africa (MENA) region, whereas sudden power drops as high as $70 \%$ from discrete meteorological events have been recorded worldwide $[1,2]$. Strategies for improving performance by limiting soiling include cleaning [3,4] and coatings [4,5]. Anti-reflective (AR) and/or anti-soiling (AS) coatings [6] may be added on the front glass to improve the throughput of incident light and/or to limit the rate and amount of contaminant accumulation. In the history of the development of PV technology [7], AR coatings gained popular use in the PV industry starting in $~ 2005$, whereas AS coatings are presently being explored. A variety of manual and automated methods may be applied for the cleaning of PV modules, typically using equipment very similar to or generally based on that used in the building glazing industry. The longevity of AR and AS coatings is presently uncertain because the coatings may be subject to abrasion damage during cleaning, erosion from airborne particulate matter in addition to certain natural processes (e.g., UV degradation, frost, and precipitation). To provide technoeconomic benefit, the cost of a coating must be sufficiently low, and the lifetime sufficiently long, to justify its use. Lastly, there is a growing interest in standardized tests that may be used to compare or further evaluate coatings used in solar panels. The requirements of the PV application, including decades of outdoor life for a device that absorbs the light of the sun, are highly demanding; therefore, they suggest the need to tailor existing normative abrasion test methods developed by the automotive, building glazing, paint, and textile industries for use with PV modules. This work aims to support the development of an abrasion test standard for the PV industry.

Representative coupon specimens are used in this study to examine the abrasion of PV first-surfaces, i.e., the surface of a module incident to direct solar radiation. Artificial linear machine abrasion using a brush has been investigated. A variety of coating materials, along with variations in the abrasive (slurry and dry-dust), and the bristle have been examined. The critical characteristics of optical performance (transmittance), surface roughness, and surface energy were correlated. The goals of this study include the following: 

The present version of several of the standards are not completely defined ("unspecified"), including the details of size of the abrasive, contact pressure, swipe length, and the cycle repeat speed. Regarding the most recent Taber tester (used in the standard BS EN 1906-2), it applies a greater contact pressure than the brush tests (ASTM D2486 and DIN 53778). It remains to be quantified if the contact pressure used in the brush tests more closely resembles the equipment and method used to clean PV modules. For example, a modest orthogonal pressure may be applied when using a water-fed, pole-mounted brush to manually clean a PV module because it may be cantilevered by a pole during cleaning. A swipe length in the order of meters, however, may be expected for PV based on the typical size of commercial modules. The conditioning of the cleaning device (e.g., soaking of brush bristles) is required for several of the brush or scrub tests. Device conditioning may occur during PV cleaning if a PV cleaning device finds use through an entire work shift. The repeat speed of 37 cycles per minute $(\mathrm{cpm})$ remains as a legacy from early mechanically enabled testers, whereas a capability from $6 \mathrm{cpm}$ to $60 \mathrm{cpm}$ is now commercially available. One variation that is allowed between brush and scrub testers is the use of constant velocity through the stroke (with all acceleration/deceleration occurring at the start/end of motion) as opposed to sinusoidal acceleration and deceleration through the stroke (which makes it easier to adjust the stroke length). Reference [7] summarizes other abrasion methods based on the use of: manual wiping, water drop impingement, abrasive shaker box, and a grinding wheel. For example, more aggressive versions of the Taber abrader in ISO 3537, ISO 15082, ASTM D1044, ASTM G195, and ASTM D4060 are typically applied in the concrete and metals industries.

Table 2 summarizes artificial machine abrasion studies in the literature of the solar PV, CSP, and CPV industries. In addition to the authors and references from the literature, the characteristics in Table 2 are the same as those used in Table 1.

The BS EN 1096-2 standard is most commonly used in the solar energy literature; however, applications to building-adapted PV or building-integrated PV are not specifically identified by the authors. Based on the present limited use of building-specific PV, the use of BS EN 1096-2 most likely results from the lack of a PVindustry-specific standard. Like PV, building glazing products also endure prolonged outdoor use. The most commonly used abrasives in Table 2 include brush bristles, Arizona (AZ) test dust, felt, or grit-embedded-disc products specific to the various Taber abrasion testers. However, the Taber abrasive products do not necessarily 
mimic the characteristics of the equipment used to clean PV modules. The experimental details in several of the studies were not completely defined ("unspecified"), including the details of size of the abrasive, contact pressure, swipe length, and the cycle repeat speed. Furthermore, the standardized test methods were not always performed exactly as specified in the normative method, with some studies being just loosely based on the test standards ("based on"). The swipe length or repeat speed provide examples where the details in Table 2 vary from the corresponding standardized test methods in Table 1. The nominal contact pressure for the brush tests in Table 2 is typically an order of magnitude less than the Taber test (BS EN 1906-2). The true area of contact for a brush may be more difficult to estimate, which suggests that the Taber test has a greater acceleration factor relative to field cleaning of PV. Most studies were performed for several hundred or a few thousand cycles. In comparison, over the course of 25 years, one cleaning per month (a complete sweep, in both forward and reverse directions) corresponds to 300 cycles; one cleaning per week corresponds to 1300 cycles; and one cleaning per day corresponds to $~ 9000$ cycles.

Other variables from the PV application were not examined or specified in the existing test standards and literature studies. The experiments summarized in Table 2 were performed at ambient laboratory conditions, whereas modules in PV installations can experience a wide variety of irradiance, temperature, and humidity conditions. However, the weather conditions and corresponding field operating conditions for cleaning are not standardized, e.g., daytime cleaning may be favored in some locations where manual cleaning is most extensively used, whereas thin-film PV may be cleaned at night to prevent shading damage. The experiments in previous solar-focused studies were not used with ultraviolet (UV) weathering or artificial soiling (and/or subsequent cementation) tests. Similarly, the acid/base chemistry at the surface (known to affect the surface through the process of glass corrosion [38]) was not explored in previous solar-focused studies. The use of a rotary brush, frequently used in PV cleaning robots [39], was also not examined in previous solar-focused studies. Many of the aforementioned limitations result from the use of a test method dedicated strictly to abrasion; the abrasion tests may subsequently be used as part of a standardized accelerated test sequence to address some of these concerns.

Although not resolving all of the limitations of the literature, certain details were chosen for the study here based on Table 1 and Table 2. It was intended to simulate PV cleaning equipment while being mindful of 
existing test standards. For this reason, a linear brush test was selected, knowing that the bristle material in several existing standards is presently being revised toward Nylon 6/12 copolymer. A moderate bristle diameter and shorter bristle length may provide accelerated testing relative to representative commercial PV brush products, i.e., diameter of $0.25-0.50 \mathrm{~mm}$ and length of $3-8 \mathrm{~cm} \mathrm{[31].} \mathrm{The} \mathrm{results} \mathrm{of} \mathrm{a} \mathrm{review} \mathrm{of} \mathrm{the} \mathrm{surface}$ contamination observed an average particulate diameter of $15 \mu \mathrm{m}$ for field-soiled PV modules [40]. A4 test dust, as in Ref. [31], is larger in diameter relative to the size of contamination present on PV in most locations. Lastly, ISO 12103-1 test dust does not account for composition, which may vary at locations throughout the world [42], [43], [44], [45], [46].

\section{MATERIALS AND METHODS}

\subsection{SPECIMENS EXAMINED}

Table 3 summarizes the coatings and materials examined in this study. The table identifies: a letter index used to refer to each specimen type; the general type of material used in the coatings (additional material added at the surface, if applicable), including fluoropolymers [47] and ceramics [35]; the thickness of coatings present (if applicable); $R_{\mathrm{a}}$, the average surface roughness $\{\mathrm{nm}\} ; A R$, the presence of an anti-reflective functionality; $\tau_{\mathrm{d}, \mathrm{rsw}}$, the direct representative solar-weighted transmittance of photon irradiance (for unaged specimens) $\{\%\}$ [48], [49]; $\Delta \tau_{\mathrm{d}, \mathrm{rsw}}$, the change in $\tau_{\mathrm{d}, \mathrm{rsw}}$ for coated specimens, relative to the substrate material $\{\%\} ; A S$, the presence of an anti-soiling coating; $C A$, the water contact angle $\left\{{ }^{\circ}\right\}$; and a general classification for the surface energy, based on the $C A$. The terms "monolithic" and "no coating" are used to identify where no coating was added. Material A was composed of poly(methyl methacrylate), i.e., solar-grade Acrylite 0Z023 (Evonik Industries AG). Porosity was not readily observed using microscopy for coating B and is therefore believed to be sub-micrometer in size; a range of pore sizes was observed for coating E (including pores in the order of micrometers in size at its surface), which would readily affect its surface roughness. The L specimens were roughened (etch depth of $150 \mathrm{~nm}$ ) at the surface with subsequent chemical processing to affect both optical performance and surface energy. Many of the coatings were applied to the surface of material J, 3.2-mm-thick Diamant low-iron glass (Saint-Gobain S.A.), which has good durability to solarization (change in transmittance based on the redox state of the glass [4],[51]) and glass corrosion [4],[38] relative to other makes of low-iron float glass. The tin-rich surface of the J glass was verified using a UV light (254 $\mathrm{nm}$ ) and then laser scribed with 













results in Table 6 and optical microscopy images in Figure 11 support this mechanism; individual scratches form first from the sharp features and corners of the abrasive (test dust) and/or brush bristles. As observed directly by optical microscopy, localized damage is accumulated with additional abrasion cycles. The cleaning of the surface (removal of an outer carbonaceous layer that is more hydrophobic than clean glass) would likely occur immediately based on local surface contact with bristles and/or dust. For specimens with surface films (i.e., specimens $\mathrm{B}, \mathrm{E}, \mathrm{P}, \mathrm{V}$, and $\mathrm{Z}$ in this study, which have a coating thickness of at least tens of nanometers) damage accumulation (as the coating is abraded) leads to a maxima in roughness along with a corresponding reduction in contact angle (increased surface energy) and a simultaneous change in $\tau_{\mathrm{d}}$ and $Y I$. Subsequent abrasion results in the destruction of the coating, revealing the smoother glass substrate, with convergence of the characteristics of $\tau_{\mathrm{d}}, Y I, C A$, and $R_{\mathrm{a}}$ to those values observed for glass. Additional abrasion would then occur across the surface of the glass. For most specimens, changes in the surface wettability as measured by $C A$-and to a lesser extent, changes in $R_{\mathrm{a}}$ - precede degradation of optical performance and can be used as early indicators of coating degradation. The characteristics of $\tau_{\mathrm{d}}, \mathrm{CA}$, and $R_{\mathrm{a}}$ proved helpful in assessing specimen integrity (particularly for coatings with a thickness), but the evaluation of performance in the field may include other characteristics not examined in this study, e.g., roll-off angle [61,62]. The natural environment contains a greater variety and complexity of chemistries and contaminants than A3 test dust and surfaces may be affected by other factors such as UV degradation of functionalized surface chemistry. Nonetheless, the correlation between the characteristics of interest here, as well as the optical microscopy results, identifies the general process of the degradation of a coating and/or surface functionalization from the linear abrasion test.

The characteristics of $Y I$ and $\lambda_{\mathrm{cUv}}$, which can be acute indicators of damage in UV weathering, are alternate- and not-recommended-characteristics for linear brush abrasion, respectively. $Y I$ and $\lambda_{\text {cuv }}$ were examined in this study to assess their usefulness for the characterization of brush abrasion. $Y I$ is determined from 300-830 $\mathrm{nm}$ [48], where the shorter UV-VIS ("blue") wavelengths are most prone to being affected by optical scattering, e.g., because the refractive index of the substrate and coatings are greater at these wavelengths. Furthermore, scattered light is not readily recovered in a $\tau_{\mathrm{d}}$ measurement, as used in this study. $Y I$ could, however, also indicate specimen discoloration if test dust became trapped in pores or embedded in a soft surface coating. The change in $Y I$ was in the order of 0 to 2 units for most specimens (not readily perceptible to 






\section{ACKNOWLEDGEMENTS}

The authors are grateful to Dr. Mike Kempe, Dr. Leo Micheli, Joshua Morse, Byron McDanold, Matt Muller, Greg Perrin, and Rob Tirawat of NREL; Fabiana Lisco of Loughborough University; James Metcalf and Dr. David Strickler of the NSG Pilkington North America. Funding was provided as part of the Durable Modules Consortium (DuraMAT), an Energy Materials Network Consortium funded under Agreement 32509 by the U.S. Department of Energy (DOE), Office of Energy Efficiency \& Renewable Energy, Solar Energy Technologies Office (EERE, SETO). This work was authored in part by the NREL, operated by Alliance for Sustainable Energy, LLC for the US DOE under contract no. DE- AC36- 08GO28308. Part of this work was performed at the Stanford Nano Shared Facilities (SNSF), supported by the National Science Foundation under award ECCS-1542152. Illya Nayshevsky gratefully acknowledges support from the City University of New York.

\section{CONFLICT OF INTEREST}

The authors declare no conflicts of interest. The views expressed in the article do not necessarily represent the views of the DOE or the U.S. government. Instruments and materials are identified in this paper to describe the experiments. In no case does such identification imply recommendation or endorsement by the National Institute of Standards and Technology or NREL. The U.S. government retains and the publisher, by accepting the article for publication, acknowledges that the U.S. government retains a nonexclusive, paid-up, irrevocable, worldwide license to publish or reproduce the published form of this work, or allow others to do so, for U.S. government purposes.

\section{REFERENCES}

1. T. Sarver, A. Al-Qaraghuli, L.L. Kazmerski, "A comprehensive review of the impact of dust on the use of solar energy: History, investigations, results, literature, and mitigation approaches," Renew. Sust. Energ. Rev., vol. 22, pp. 698-733, 2013.

2. J.M. Freese, Effects of outdoor exposure on the solar reflectance properties of silvered glass mirrors, SAND 78-1649, 1978, 1-31.

3. "Cleaning of soiled facades," in The Soiling and Cleaning of Building Facades, L.G.W. Verhoef, Ed., London: Taylor \& Francis, 1988, pp. 124-135.

4. D.C. Miller, S.R. Kurtz, "Durability of Fresnel lenses: A review specific to the concentrating photovoltaic application," Solar Energy Materials and Solar Cells, 95 (8), 2011, 2037-2068. (DOI:10.1016/j.solmat.2011.01.031)

5. A. Einhorn, L. Micheli, D.C. Miller, L.J. Simpson, H.R. Moutinho, B. To, C.L. Lanaghan, M.T. Muller, S. Toth, J.J. John, S. Warade, A. Kottantharayil, C. Engtrakul, "Evaluation of soiling and potential mitigation approaches on photovoltaic glass," IEEE Journal of Photovoltaics, 9 (1), 2018, 233-239.

6. H. Kumar Raut, V.A. Ganesh, A.S. Nair, S. Ramakrishna, "Anti-reflective coatings: A critical, in-depth review," Energy Environ. Sci., 4, 2011, 3779.

7. J.H. Wohlgemuth, Photovoltaic Module Reliability, Hoboken: John Wiley \& Sons, Inc., 2020. 

32. X. Pan, S. Zhang, J. Xu, Z. Feng, P.J. Verlinden, "Performance of different anti-reflective coated glass for PV modules," Proc. Euro. PVSEC 2015.

33. S.C. Pop, V. Abbaraju, B. Brophy, Y.S. Yang, S. Maghsoodi, P. Gonsalves, "A highly abrasive-resistant, long-lasting anti-reflective coating for PV module glass," Proc. IEEE PVSC (2014): 2715-2719.

34. T. Weber, M. Hanusch, S. Koch, M. Trawny, A. Janker, A. Böttcher, J. Berghold, P. Grunow, "From the impact of harsh climates and environmental conditions on PV modules-Development of a soiling and abrasion test," Proc. Euro. PVSEC, 2014.

35. G. Womack, P.M. Kaminski, A. Abbas, K. Isbilir, R. Gottschalg, J.M. Walls, "Performance and durability of broadband antireflection coatings for thin film CdTe solar cells," J. Vac. Sci. Technol. A 35, 021201 (2017); doi: 10.1116/1.4973909.

36. K. Isbilir, B. Maniscalco, R. Gottschalg, J.M. Walls, "Test methods for hydrophobic coatings on solar cover glass," Proc. IEEE PVSC Conf., 2017, 18188967. doi: 10.1109/PVSC.2017.8366246

37. G. Womack, K. Isbilir, F. Lisco, G. Durand, A. Taylor, J.M. Walls, "The performance and durability of single-layer sol-gel anti-reflection coatings applied to solar module cover glass," Surf. Coat. Technol. 358, 2019, 76-83.

38. C.G. Pantano, D.E. Clark, L.L. Hench, Corrosion of Glass, Books for Industry and the Glass Industry: New York, 1979.

39. G.P. Choori, “An overview of robotic cleaning systems,” Proc. Intl. Soiling Work., 2017.

40. I. Nayshevsky, Q.F. Xu, A.M. Lyons, "Literature Survey of Dust Particle Dimensions on Soiled Solar Panel Modules", Mendeley Data, http://dx.doi.org/10.17632/gt2h83ssb5

41. "ISO 12103-1: Road Vehicles-Test Contaminants for Filter Evaluation-Part 1: Arizona Test Dust," International Standards Organization: Geneva, 2016, pp. 1-14.

42. J.J. John, S. Warade, G. Tamizhmani, A. Kottantharayil, "Study of soiling loss on photovoltaic modules with artificially deposited dust of different gravimetric densities and compositions collected from different locations in India," IEEE J PV, 6 (1), 2016, 236-243.

43. A. Alnuaimi, J. John, O. Albadwawi, Y. Elhassan, F. Albanna, F. Almamari, A. Alqassim, "Quantification of spectral losses of natural soiling and detailed microstructural analysis of dust collected from different locations in Dubai, UAE," Proc IEEE PVSC Conf., 2019, xxx. 10.1109/PVSC40753.2019.8980937

44. J.P. Engelbrecht, E.V. McDonald, J.A. Gillies, R.K.M. Jayanty, G. Casuccio, A.W. Gertler, "Characterizing mineral dusts and other aerosols from the Middle East-Part 1: Ambient sampling," Inhalation Toxicology, 21, 2009, 297-326.

45. J.P. Engelbrecht, E.V. McDonald, J.A. Gillies, R.K.M. Jayanty, G. Casuccio, A.W. Gertler, "Characterizing mineral dusts and other aerosols from the Middle East-Part 2: Grab samples and re-suspensions, 21, 2009, 327-336.

46. W. Javed, Y. Wubulikasimu, B. Figgis, and B. Guo, "Characterization of dust accumulated on photovoltaic panels in Doha, Qatar," Solar Energy 142 (2017) 123-135.

47. Nayshevsky, Q. F. Xu, G. Barahman, and A. M. Lyons, "Fluoropolymer coatings for solar cover glass: Antisoiling mechanisms in the presence of dew," Solar Energy Materials and Solar Cells, 206, 2020, 110281. https://doi.org/10.1016/j.solmat.2019.110281 .

48. D.C. Miller, J. Apezteguia, J.G. Bokria, M. Köhl, N.E. Powell, M.E. Smith, M.D. White, H. Rose Wilson, J.H. Wohlgemuth, "Examination of an optical transmittance test for photovoltaic encapsulation materials," Proc SPIE, 2013, 8825-8.

49. IEC 62788-1-4 Measurement procedures for materials used in photovoltaic modules - Part 1-4: Encapsulants-Measurement of optical transmittance and calculation of the solar-weighted photon transmittance, yellowness index, and UV cut-off wavelength," International Electrotechnical Commission: Geneva, 1-37, 2016.

50. P.M. Kaminski, G. Womack, J.M. Walls, "Broadband anti-reflection coatings for thin film photovoltaics," Proc. IEEE PVSC Conf., 2014, 2778-2783.

51. W. Thiemsorn, K. Keowkamnerd, S. Phanichphant, P. Suwannathada, H. Hessenkemper, "Influence of glass basicity on redox interactions of iron-manganese-copper ion pairs in soda-lime-silica glass," Glass Phys. Chem., 34 (2008), 19-29.

52. J.M. Newkirk, I. Nayshevsky, A. Sinha, A. Law, Q. Xu, B. To, P.F. Ndione, L.T. Schelhas, J.M. Walls, A.M. Lyons, D.C. Miller, "Artificial Linear Brush Abrasion of Coatings for Photovoltaic Module First Surfaces,” Intl. PV Soling Work., NREL-PR-5K00-75028, 2019, xxx. 
53. P.B. Johnson, R.W. Christy. "Optical constants of the noble metals," Phys. Rev. B, 6, 1972, 4370-4379.

54. M. Rubin, "Optical properties of soda lime glasses," Solar Energy Mats., 12, 1985, 275-288.

55. David C. Miller, Joseph D. Carloni, David K. Johnson, Joel W. Pankow, Erica L. Gjersing, Bobby To, Corinne E. Packard, Cheryl E. Kennedy, and Sarah R. Kurtz, "An Investigation of the Changes in Poly(Methyl Methacrylate) Specimens After Exposure to Ultra-Violet, Heat, and Humidity”, Solar Energy Materials and Solar Cells, 111, 2013, 165-180. (DOI: dx.doi.org/10.1016/j.solmat.2012.05.043)

56. J.M. Walls, P.M. Kaminski, “Cover sheet for photovoltaic panel,” UK patent 1821095.5, 2018.

57. A.M Law, P.M. Kaminski, P.J.M. Isherwood, J.M. Walls, "An infra-red reflecting optical coating for solar cover glass," Proc. IEEE PVSC Conf., 2019, xxx. 10.1109/PVSC40753.2019.8981269

58. Y. Yamamoto, K. Yamamoto, "Precise XPS depth profile of soda-lime-silica glass using C60 ion beam", J Non-Crystl. Sol., 356, 2010, 14-18.

59. C.L. Perkins, M. Muller, L. Simpson, "Laboratory Studies of Particle Cementation and PV module soiling," Proc. IEEE PVSC, 2017, 2294-2297.

60. J.O. Aguilar, J.M Rodríguez-Lelis, M.J. Arjona, "Iron oxide coating films in soda-lime glass by triboadhesion," J. Mech. Sci. Technol., 23, 2009, 1169-1174

61. ISO 19403-7, Paints and Varnishes—Wettability—Part 7: Measurement of the contact angle on a Tilt Stage (Roll-Off Angle) (International Organization for Standardization: Geneva, 2017), 1-13.

62. G.C. Oehler, F. Lisco, F. Bukhari, S. Uličná, B. Strauss, K.L. Barth, J.M. Walls, "Testing the durability of anti-soiling coatings for solar cover glass by outdoor exposure in Denmark", Energies, 13, 2019, 1-17, doi:10.3390/en13020299.

63. A.J. Cox, "An experiment to measure Mie and Rayleigh total scattering cross sections". Amer. J. Phys., 70 (6), 2002, 620-625. https://doi.org/10.1119/1.1466815 
Figure 1: Representative images of the experimental configurations, including: (a) isometric view of the slurry tester, (b) isometric view of the dry-dust tester, and (c) top-down view of an abraded specimen. Key components are labeled in the figure.

Figure 2: Representative direct transmittance spectra (obtained with no integrating sphere) for select specimens with no abrasion. A subset of the transmittance (measured from $0 \%-100 \%$ ) and wavelengths examined (measured from 200-2500 nm) are shown.

Figure 3: Slurry test - optical measurements: comparison of the change in transmittance (i.e., coating optical performance) and yellowness index (which may vary with optical scattering) with the cumulative brush-cycle count $(n \leq 5000)$ for select coatings for artificial linear brush abrasion. The experiments in Figure 3 and Figure 4 compare specimens with a variety of surface treatments, surface functionalizations, and coating materials.

Figure 4: Slurry test - surface measurements: comparison of the change in surface energy (contact angle for water) and average surface roughness with the cumulative brush-cycle count $(n \leq 5000)$ for select coatings for linear abrasion.

Figure 5: Dry dust test - optical measurements: comparison of the change in transmittance and yellowness index with the brush-cycle count $(\mathrm{n} \leq 5000)$ for select coatings for linear abrasion. The experiments in Figure 5 and Figure 6 compare specimens with a variety of surface treatments, surface functionalizations, and coating materials.

Figure 6: Dry dust test - surface measurements: comparison of the change in surface energy and surface roughness with the brush-cycle count $(\mathrm{n} \leq 5000)$ for select coatings for linear abrasion.

Figure 7: Effect of abrasion test type on coating P: comparison of the change in transmittance and yellowness index with the brush-cycle count $(\mathrm{n} \leq 20000)$ for select linear abrasion experiments. The experiments in Figure 7 and Figure 8 compare a variety of methods that may be used to affect the rate of linear abrasion of the same coating. 

Tables:

Table 1: Summary of the standardized test methods for artificial machine abrasion from the building, paint, and automotive-window industries that could be applied for solar applications.

\begin{tabular}{|c|c|c|c|c|c|c|c|}
\hline $\begin{array}{l}\text { TEST } \\
\text { METHOD }\end{array}$ & $\begin{array}{l}\text { INDUSTRY } \\
\text { OF ORIGIN }\end{array}$ & $\begin{array}{l}\text { ABRASIVE } \\
\text { MATERIAL }\end{array}$ & $\begin{array}{l}\text { SIZE ABRASIVE } \\
\text { (GEOMETRY) } \\
\{\mathrm{mm}\}\end{array}$ & $\begin{array}{c}\text { NOMINAL } \\
\text { CONT ACT } \\
\text { PRESSURE } \\
\{\mathrm{kPa}\} \\
\end{array}$ & $\begin{array}{c}\text { STROKE } \\
\text { LENGTH } \\
\{\mathrm{mm}\}\end{array}$ & $\begin{array}{c}n, \text { NUMBER } \\
\text { OF CYCLES } \\
\text { \{dimensionless\} }\end{array}$ & $\begin{array}{c}\text { CYCLE REPEAT SPEED } \\
\{\mathrm{cpm}\}\end{array}$ \\
\hline BS EN 1096-2 (Annex E) [9] & $\begin{array}{c}\begin{array}{c}\text { bulding } \\
\text { glazings }\end{array} \\
\end{array}$ & felt or grit embedded rubber tip & $\begin{array}{l}14.5 \text { or } 7 \\
\text { (diameter) }\end{array}$ & 24.2 or 103.9 & 120 & 500 & 60 \\
\hline AST M D2486 [10] & paints & $\begin{array}{c}\text { wet Nylon } 6 \text { bristles } \\
\text { plus silica, surfactant slurry }\end{array}$ & $\begin{array}{c}35 \times 85 \text { (area); } \\
19 \text { (length) \& } 0.30(Æ)\end{array}$ & 1.5 & 270 & $\begin{array}{l}\text { pre-condition brush } 400 \text { cycles; } \\
\text { test } 400 \text { cycle increments to failure }\end{array}$ & 37 \\
\hline DIN $53778-2[11]$ & paints & $\begin{array}{l}\text { wet hogs bristle plus } \\
\text { sodium-n-dodecylbenzenesulphonate } \\
\text { in water }\end{array}$ & $\begin{array}{l}38 \times 89 \text { (area); } \\
10.5 \text { (length) }\end{array}$ & 0.7 & 270 & $\begin{array}{l}\text { pre-condition brush } 1000 \text { cycles; } \\
\text { test \# cycles to failure }\end{array}$ & $\begin{array}{c}\text { not } \\
\text { specified }\end{array}$ \\
\hline ISO 11998 [12] & paints & $\begin{array}{c}\text { wet steel wool pad plus } \\
\text { sodium-n-dodecylbenzenesulphonate } \\
\text { in water } \\
\end{array}$ & $\begin{array}{l}39 \times 90 \text { (area); } \\
38 \text { (thick) }\end{array}$ & $\begin{array}{c}\text { not } \\
\text { specified }\end{array}$ & 300 & pre-soak; 200 cycles & 37 \\
\hline ASTM D4213 [13] & paints & $\begin{array}{c}\text { wet steel wool pad } \\
\text { plus cellulose, surfactant slurry }\end{array}$ & $\begin{array}{c}77 \times 97 \text { (area); } \\
6 \text { (thick) }\end{array}$ & $\begin{array}{c}\text { not } \\
\text { specified }\end{array}$ & 255 & $\begin{array}{c}\text { pre-soak; } 200 \text { cycle increment } \\
\text { test up to } 800 \text { cycles }\end{array}$ & $\begin{array}{c}\text { not } \\
\text { specified }\end{array}$ \\
\hline ASTM D3450 [14] & $\begin{array}{c}\text { architectural } \\
\text { coatings }\end{array}$ & $\begin{array}{c}\text { damp cellulose sponge } \\
\text { with silica, surfactant slurry }\end{array}$ & $\begin{array}{c}76 \times 95 \text { (area); } \\
38 \text { (thick) }\end{array}$ & 2.0 & $\begin{array}{c}\text { not } \\
\text { specified }\end{array}$ & $0,25,50,75,100$ & 37 \\
\hline ASTM D4828 [15] & paints & unspecified sponge & $\begin{array}{c}\text { not } \\
\text { specified }\end{array}$ & $\begin{array}{c}\text { not } \\
\text { specified }\end{array}$ & 255 & 100 & 37 \\
\hline UN/ECE Regulation 43 [16] & $\begin{array}{c}\text { automotive } \\
\text { glazings }\end{array}$ & $\begin{array}{l}\text { chloroprene rubber wiper blade plus } \\
\text { ISO } 12103 \mathrm{~A} 4 \text { dust }\end{array}$ & 11 (length) & $\begin{array}{c}\text { not } \\
\text { specified }\end{array}$ & 130 & $10 \mathrm{k}$ plus $10 \mathrm{k}$ cycles & 37 \\
\hline $\begin{array}{c}\text { ISO } 15082[17] \\
\text { ISO 20566 [18] } \\
\text { UN/ECE Regulation } 43[16] \\
\end{array}$ & $\begin{array}{c}\text { automotive } \\
\text { glazings }\end{array}$ & $\begin{array}{l}\text { polyethylene brush plus } \\
24 \mathrm{~mm} \varnothing \text { silica slurry }\end{array}$ & 440 (long) \& $0.8(Æ)$ bristles & $\begin{array}{c}\text { not } \\
\text { specified }\end{array}$ & $>300$ & 10 cycles & $\begin{array}{c}30 \mathrm{cpm} \text { (linear) } \\
127 \mathrm{rpm} \text { (rotation) }\end{array}$ \\
\hline ISO 3537 [19] & $\begin{array}{c}\text { automotive } \\
\text { glazings }\end{array}$ & abrasive or grit embedded wheel & $\begin{array}{c}12.7 \text { (wheel width) } \\
44.4-52.5 \text { (wheel } Æ \text { ) }\end{array}$ & $\begin{array}{c}\text { not } \\
\text { specified }\end{array}$ & N/A & 100,500 , or 1000 & rotate at $60 \mathrm{rpm}$ or $72 \mathrm{rpm}$ \\
\hline ISO 15082 [17] & $\begin{array}{c}\text { automotive } \\
\text { glazings }\end{array}$ & $\mathrm{Al}_{2} \mathrm{O}_{3}$ or $\mathrm{SiC}$ grit embedded in matrix & $\begin{array}{c}12.7 \text { (wheel width) } \\
44.4-52.5 \text { (wheel } Æ \text { ) }\end{array}$ & $\begin{array}{c}\text { not } \\
\text { specified }\end{array}$ & $\mathrm{N} / \mathrm{A}$ & 100,500 , or 1000 & rotate at $60 \mathrm{rpm}$ or $72 \mathrm{rpm}$ \\
\hline $\begin{array}{c}\text { ASTM D1044 [20] } \\
\text { ASTM G195 [21] } \\
\end{array}$ & $\begin{array}{c}\text { transparent plastics } \\
\text { general use } \\
\end{array}$ & abrasive or grit embedded rubber wheel & $\begin{array}{c}12.7 \text { (wheel width) } \\
44.4-52.5 \text { (wheel } Æ \text { ) } \\
\end{array}$ & $\begin{array}{c}\text { not } \\
\text { specified }\end{array}$ & $\mathrm{N} / \mathrm{A}$ & $\begin{array}{c}10,25,50,100 ; \\
\text { user defined }\end{array}$ & rotate at $60 \mathrm{rpm}$ or $72 \mathrm{rpm}$ \\
\hline ASTM D4060 [22] & paints & abrasive or grit embedded rubber wheel & $\begin{array}{c}12.7 \text { (wheel width) } \\
44.4-52.5 \text { (wheel } Æ \text { ) }\end{array}$ & $\begin{array}{c}\text { not } \\
\text { specified }\end{array}$ & $\mathrm{N} / \mathrm{A}$ & $\begin{array}{l}50 \text { cycle increment } \\
\text { test up to } 500 \text { cycles }\end{array}$ & rotate at $60 \mathrm{rpm}$ or $72 \mathrm{rpm}$ \\
\hline
\end{tabular}

Table 2: Summary of abrasion studies in the solar energy research literature.

\begin{tabular}{|c|c|c|c|c|c|c|c|}
\hline $\begin{array}{l}\text { AUTHORS, } \\
\text { REFERENCE }\end{array}$ & $\begin{array}{c}\text { TEST } \\
\text { METHOD }\end{array}$ & $\begin{array}{l}\text { ABRASIVE } \\
\text { MATERIAL }\end{array}$ & $\begin{array}{c}\text { SIZE TEST FIXTURE } \\
\text { (GEOMETRY) } \\
\{\mathrm{mm}\}\end{array}$ & $\begin{array}{c}\text { NOMINAL } \\
\text { CONT ACT } \\
\begin{array}{c}\text { PRESSURE } \\
\{\mathrm{kPa}\}\end{array}\end{array}$ & $\begin{array}{c}\text { STROKE } \\
\text { LENGTH } \\
\{\mathrm{mm}\}\end{array}$ & $\begin{array}{c}n, \text { NUMBER } \\
\text { OF CYCLES } \\
\text { \{dimensionless\} }\end{array}$ & $\begin{array}{c}\text { CYCLE } \\
\text { REPEAT } \\
\text { SPEED } \\
\{\mathrm{cpm}\}\end{array}$ \\
\hline Bengoechea et. al. [23] & based on BS EN 1096-2 & $\begin{array}{l}\text { Nylon } 6 / 6 \text { bristles with } \mathrm{SiO}_{2} \text { sand, } \\
\text { Aramco test dust, or silica }\end{array}$ & $\begin{array}{c}20 \times 40 \text { (area) } \\
0.060 £ £ £ 0.200\end{array}$ & 2.5 & 70 & 200 & 120 \\
\hline Cauchois et. al. [24] & based on BS EN 1096-2 & $\begin{array}{c}\text { felt or } \\
\text { grit embedded rubber tip }\end{array}$ & $\begin{array}{c}\text { not } \\
\text { specified }\end{array}$ & $\begin{array}{c}\text { not } \\
\text { specified }\end{array}$ & $\begin{array}{c}\text { not } \\
\text { specified }\end{array}$ & $\begin{array}{c}10,20,50,100,150,200,250 \\
500,1 \mathrm{k}, 2 \mathrm{k}, 4 \mathrm{k}, 6 \mathrm{k}, 10 \mathrm{k}\end{array}$ & $\begin{array}{c}\text { not } \\
\text { specified }\end{array}$ \\
\hline $\begin{array}{l}\text { Ferretti et. al. [25] } \\
\text { Ferretti et. al. [26] }\end{array}$ & BS EN 1096-2 & grit embedded rubber & $\begin{array}{c}7 \\
\text { (diameter) }\end{array}$ & 90.9 & 100 & $0,25,50,250,500,1 \mathrm{k}$ & 60 \\
\hline Ferretti et. al. [27] & custom rotary brush & $\begin{array}{c}\text { CT P-300-3 Method } 313 \text { sand [28]; } \\
\text { PA } 6 \text { bristle }\end{array}$ & $\begin{array}{c}0.16 \text { or } 0.42(Æ) ; \\
40 \text { (length) \& } 0.3(Æ)\end{array}$ & $\begin{array}{c}\text { not } \\
\text { specified }\end{array}$ & module length & $1 \mathrm{k}$ & $\begin{array}{c}\text { not } \\
\text { specified }\end{array}$ \\
\hline Klimm et. al., [29] & BSEN 1096-2 & felt & $\begin{array}{c}14.5 \\
\text { (diameter) }\end{array}$ & 24.2 & 120 & $0,500,1 \mathrm{k}, 1.5 \mathrm{k}$ & 60 \\
\hline Lange et. al. [30] & ISO 11998 & $\begin{array}{c}\text { PA bristle; } \\
\text { ISO } 12103 \mathrm{~A} 2 \text { test dust }[\mathrm{xxx}]\end{array}$ & $\begin{array}{c}35 \times 85 \text { (area) } \\
19 \mathrm{~mm} \text { (length); }\end{array}$ & 1.5 & 100 & $0,10,50,100$ & 72 \\
\hline Miller et. al. [31] & based on ASTM D2486 & $\begin{array}{l}\text { bristles: PA, hog bristle, PE, horsehair; } \\
\text { ISO } 12103 \text { A4 test dust [xxx] }\end{array}$ & $\begin{array}{c}35 \times 85 \text { (area) } \\
19,38 \text { (length) } \\
0.30,0.64,0.22,0.25(Æ) ;\end{array}$ & 1.5 & 270 & $0,100,500,1 \mathrm{k}, 5 \mathrm{k}, 10 \mathrm{k}, 20 \mathrm{k}$ & 37 \\
\hline Pan et. al., [32] & BS EN 1096-2 & felt & $\begin{array}{c}\text { not } \\
\text { specified }\end{array}$ & $\begin{array}{c}\text { not } \\
\text { specified }\end{array}$ & $\begin{array}{c}\text { not } \\
\text { specified }\end{array}$ & $0,500,1 \mathrm{k}, 2 \mathrm{k}, 5 \mathrm{k}$ & $\begin{array}{c}\text { not } \\
\text { specified }\end{array}$ \\
\hline Pop et. al., [33] & BS EN 1096-2 & felt & $\begin{array}{c}14.5 \\
\text { (diameter) } \\
\end{array}$ & 24.2 & 100 & $0,200,400,600,800,1 \mathrm{k}$ & 30 \\
\hline Weber et. al., [34] & BSEN 1096-2 & $\begin{array}{c}\text { felt } \\
\text { grit embedded rubber }\end{array}$ & $\begin{array}{c}7 \\
\text { (diameter) }\end{array}$ & 103.9 & 100 & $0,50,100,250,1 \mathrm{k}$ & 60 \\
\hline $\begin{array}{l}\text { Womack et. al. [35] } \\
\text { Isbilir et. al. [36] } \\
\text { Womack et. al. [37] }\end{array}$ & BS EN 1096-2 & $\begin{array}{c}\text { felt } \\
\text { grit embedded rubber }\end{array}$ & $\begin{array}{c}7 \\
14.5 \\
\text { (diameter) }\end{array}$ & $\begin{array}{c}259.8 \\
30.3 \& 60.6\end{array}$ & 30 & 100 & 60 \\
\hline
\end{tabular}


Table 3: Summary of the coatings and materials examined in this study, including their physical, anti-reflective (AR), and anti-soiling (AS, shown for water) characteristics.

\begin{tabular}{|c|c|c|c|c|c|c|c|c|c|}
\hline $\begin{array}{l}\text { SPECIMEN } \\
\text { INDEX }\end{array}$ & $\begin{array}{l}\text { COATING OR } \\
\text { MATERIAL }\end{array}$ & $\begin{array}{c}\text { COATING } \\
\text { THICKNESS } \\
\{\mathrm{nm}\}\end{array}$ & $\begin{array}{c}R_{\mathrm{a}}, \text { COATING } \\
\text { ROUGHNESS } \\
\qquad\{\mathrm{nm}\}\end{array}$ & $\mathrm{AR}$ & $\begin{array}{l}\tau_{\mathrm{d}, \mathrm{rsw}} \\
\{\%\}\end{array}$ & $\begin{array}{c}\Delta \tau_{\mathrm{d}, \mathrm{rsw}} \\
\{\%\}\end{array}$ & $\begin{array}{c}\text { AS } \\
\text { SURFACE } \\
\text { FUNCTIONALIZATION }\end{array}$ & $\begin{array}{c}C A, \\
\text { CONTACT } \\
\text { ANGLE } \\
\left\{^{\circ}\right\}\end{array}$ & $\begin{array}{c}\text { WETTING } \\
\text { CHARACTERISTIC }\end{array}$ \\
\hline A & monolithic PMMA & no coating & 3.6 & no & 89.2 & N/A & no & 70 & least-hydrophilic \\
\hline $\mathrm{B}$ & porous silica* & 125 & 4.6 & yes & 91.8 & 1.7 & yes & 88 & least-hydrophilic \\
\hline $\mathrm{E}$ & porous silica* & 130 & 25.3 & yes & 93.0 & 2.3 & no & 49 & moderately-hydrophilic \\
\hline $\mathrm{J}$ & $\begin{array}{c}\text { monolithic } \\
\text { glass substrate }\end{array}$ & no coating & 3.4 & no & 90.1 & N/A & no & 43 & moderately-hydrophilic \\
\hline $\mathrm{L}$ & etched glass & no coating & 5.5 & yes & 90.8 & 0.7 & yes & 50 & moderately-hydrophilic \\
\hline $\mathrm{P}$ & polymer & 40 & 5.0 & yes & 90.8 & 0.6 & yes & 118 & hydrophobic \\
\hline $\mathrm{R}$ & silane chemistry & no coating & 3.4 & no & 90.2 & 0.1 & yes & 102 & hydrophobic \\
\hline $\mathrm{V}$ & $\mathrm{TiO}_{2}^{+}$ & 50 & 2.2 & no & 79.3 & -7.5 & yes & 45 & moderately-hydrophilic \\
\hline $\mathrm{Z}$ & $\mathrm{ZrO}{ }_{2} / \mathrm{SiO}_{2} / \mathrm{ZrO}_{2} / \mathrm{SiO}_{2}$ & $20 / 30 / 135 / 95$ & 7.4 & yes & 90.2 & 0.1 & no & 9 & most-hydrophilic \\
\hline
\end{tabular}

Table 4: Summary of the artificial linear machine abrasion experiments performed in this study, including the "material," brush, wet and/or dry test conditions, use of abrasive, and cycle count.

\begin{tabular}{|c|c|c|c|c|c|}
\hline $\begin{array}{c}\text { SPECIMEN } \\
\text { INDEX }\end{array}$ & BRUSH & $\begin{array}{c}\text { WET } \\
\text { TEST }\end{array}$ & $\begin{array}{c}\text { DRY } \\
\text { TEST }\end{array}$ & $\begin{array}{c}\text { ABRASIVE } \\
\text { PRESENT }\end{array}$ & $\begin{array}{c}n, \text { NUMBER OF CYCLES } \\
\text { dimensionless }\}\end{array}$ \\
\hline \hline $\mathrm{A}$ & default & Y & Y & ISO 12103 A3 & $0,10,25,50,75,100,5 \mathrm{k}$ \\
\hline $\mathrm{B}$ & default & Y & Y & ISO 12103 A3 & $0,10,25,50,75,100,5 \mathrm{k}$ \\
\hline $\mathrm{E}$ & default & Y & Y & ISO 12103 A3 & $0,10,25,50,75,100,5 \mathrm{k}$ \\
\hline $\mathrm{J}$ & default & $\mathrm{Y}$ & $\mathrm{Y}$ & ISO 12103 A3 & $0,10,25,50,75,100,5 \mathrm{k}, 10 \mathrm{k}, 20 \mathrm{k}$ \\
\hline $\mathrm{L}$ & default & $\mathrm{Y}$ & $\mathrm{Y}$ & ISO 12103 A3 & $0,10,25,50,75,100,5 \mathrm{k}$ \\
\hline $\mathrm{P}$ & default & $\mathrm{Y}$ & $\mathrm{Y}$ & ISO 12103 A3 & $0,10,25,50,75,100,5 \mathrm{k}$ \\
\hline $\mathrm{P}$ & default & $\mathrm{Y}$ & $\mathrm{Y}$ & none & $0,10,100,500,1 \mathrm{k}, 5 \mathrm{k}, 10 \mathrm{k}$ \\
\hline $\mathrm{P}$ & soft bristle & $\mathrm{Y}$ & $\mathrm{N}$ & ISO 12103 A3 & $0,10,100,500,1 \mathrm{k}, 5 \mathrm{k}, 10 \mathrm{k}$ \\
\hline $\mathrm{R}$ & default & $\mathrm{Y}$ & $\mathrm{Y}$ & ISO 12103 A3 & $0,10,25,50,75,100,5 \mathrm{k}$ \\
\hline $\mathrm{V}$ & default & $\mathrm{Y}$ & $\mathrm{N}$ & ISO 12103 A3 & $0,10,100,500,1 \mathrm{k}, 5 \mathrm{k}, 10 \mathrm{k}, 20 \mathrm{k}$ \\
\hline $\mathrm{Z}$ & default & $\mathrm{Y}$ & $\mathrm{N}$ & ISO $12103 \mathrm{~A} 3$ & $0,10,100,500,1 \mathrm{k}, 5 \mathrm{k}, 10 \mathrm{k}, 20 \mathrm{k}$ \\
\hline
\end{tabular}
















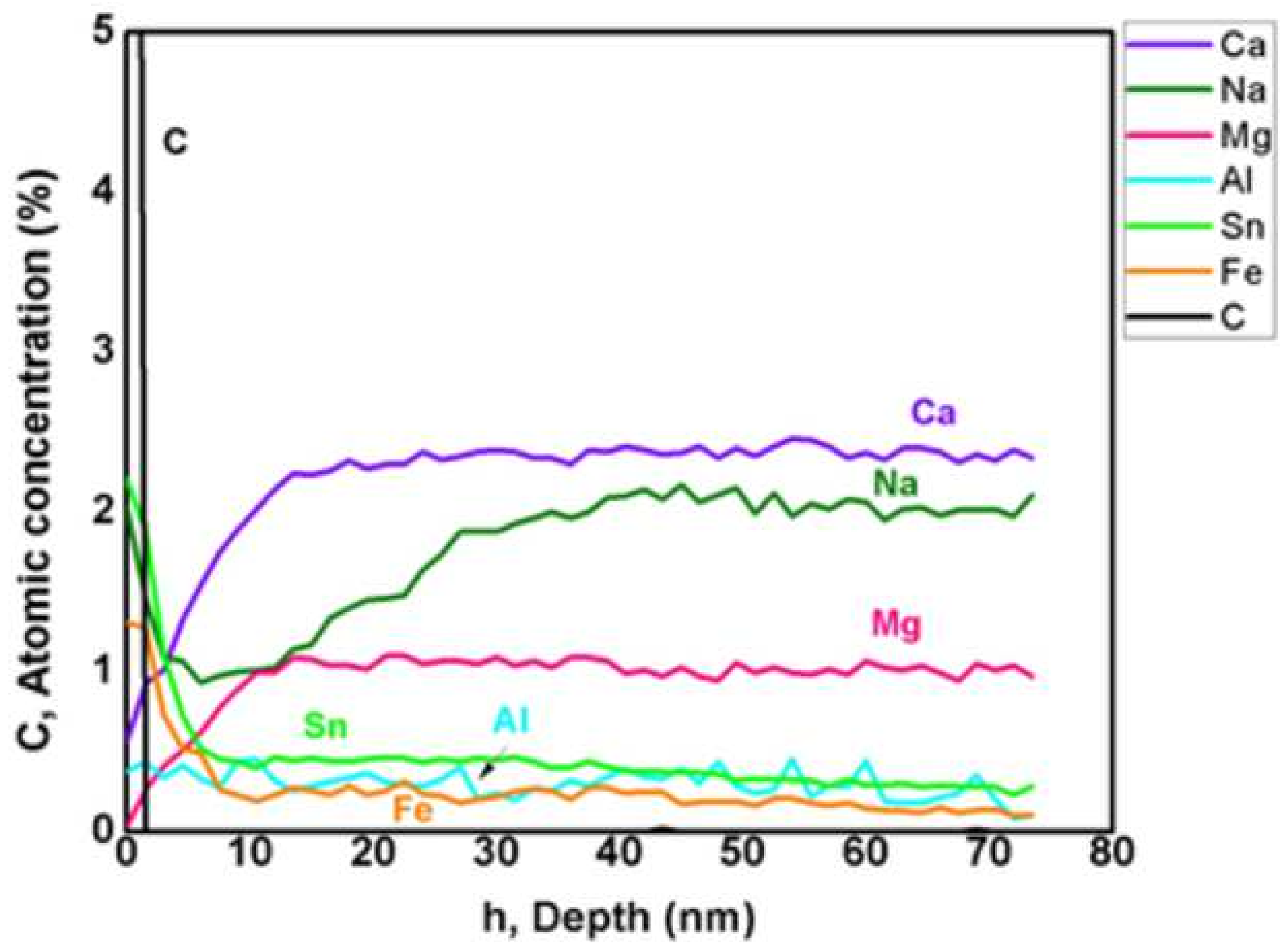



Click here to access/download RDM Data Profile XML SOLMAT-D-20-00306_DataProfile.xml 


\section{Declaration of interests}

$\bigotimes$ The authors declare that they have no known competing financial interests or personal relationships that could have appeared to influence the work reported in this paper.

"The authors declare no conflicts of interest. The views expressed in the article do not necessarily represent the views of the DOE or the U.S. government. Instruments and materials are identified in this paper to describe the experiments. In no case does such identification imply recommendation or endorsement by the National Institute of Standards and Technology or NREL. The U.S. government retains and the publisher, by accepting the article for publication, acknowledges that the U.S. government retains a nonexclusive, paid-up, irrevocable, worldwide license to publish or reproduce the published form of this work, or allow others to do so, for U.S. government purposes."

$\square$ The authors declare the following financial interests/personal relationships which may be considered as potential competing interests: 

Click here to access/download Supplementary material DCM_SOLMAT_2020_08_10_SUPPLEMENTAL.pdf 